\title{
The Role of Colistin in Urinary Tract Infections in the Neurologic Patient
}

\author{
ANDREEA CRISTINA STOIAN ${ }^{1}$, FLORENTINA DUMITRESCUㄴ, RALUCA ELENA SANDU²*,ANDREEA LILI BARBULESCU³, \\ FLORENTIN ANANU VREJ U4, OANA ANDREEA FLORESCU5 , BOGDAN CATALIN ${ }^{6}$, EMILIA BURADA, \\ ANCA EMANUELA MUSATESCU ${ }^{4}$, CARMEN VALERIA ALBU 7 \\ ${ }^{1}$ University of Medicine and Pharmacy of Craiova, Infectious Disease Department, 2 Petru Rares Str., 200349, Craiova, \\ Romania \\ 2University of Medicine and Pharmacy of Craiova, Biochemistry Department, 2 Petru Rares Str., 200349, Craiova, Romania \\ 3University of Medicine and Pharmacy of Craiova, Pharmacology Department, 2 Petru Rares Str., 200349, Craiova, Romania \\ ${ }^{4}$ University of Medicine and Pharmacy of Craiova, Rheumatology Department, 2 Petru Rares Str., 200349, Craiova, Romania \\ 5University of Medicine and Pharmacy of Craiova, PhD student, Radiology and Imaging Department, 2 Petru Rares Str., \\ 200349, Craiova, Romania \\ UUniversity of Medicine and Pharmacy of Craiova, Physiology Department, 2 Petru Rares Str., 200349, Craiova, Romania \\ ZUniversity of Medicine and Pharmacy of Craiova, Neurology Department, 2 Petru Rares Str., 200349, Craiova, Romania \\ ${ }^{8}$ University of Medicine and Pharmacy of Craiova, Medical Rehabilitation Department, 2 Petru Rares Str., 200349, Craiova, \\ Romania
}

\begin{abstract}
Urinary tract infections represent a frequent, infectious casuistry of the neurologic patient, often recurrent, with the significant involvement of multidrug-resistant bacteria (MDRs). A retrospective study, during the period 01.01.2018-31.12.2018, in the Clinical Neurology Hospital in Craiova, on a group of 334 Px with urinary tract infections and proven microbial etiology (positive urocultures), for whom antibiograms were performed using KIRBY-BAUER disk diffusion test. The duplicates and samples considered contaminated were excluded from the study. Urinary tractinfections are frequently encountered in the neurologic patient, the major etiology being represented by $E$. coli; the risk of multidrug-resistance is not to be neglected, Klebsiella pn being the most common in such a situation.
\end{abstract}

Keywords: urinary tract infections, Colistin, multidrug-resistant strains, neurological pathology

Urinary tract infections represent a frequent, infectious casuistry of the neurologic patient, often recurrent, with the significant involvement of multidrug-resistant bacteria (MDRs). Colistin is a rescue therapy in such critical situations, with proven efficacy and safety profile [1], alone or in combination with other antibiotics [2].

Objectives: Bacteriological and therapeutical analysis of urinary tract infections (UTI) in the neurologic patient $(\mathrm{Px})$.

\section{Experimental part}

Material and method: A retrospective study, during the period 01.01.2018-31.12.2018, in the Clinical Neurology Hospital in Craiova, on a group of $334 \mathrm{Px}$ with urinary tract infections and proven microbial etiology (positive urocultures), for whom antibiograms were performed using KIRBY-BAUER disk diffusion test. The duplicates and samples considered contaminated were excluded from the study.

Antibiotic sensitivity was defined as: very high: 90-100\%, high: $80-89.99 \%$, medium: 50-79.99\%, low < 50\%. Multidrug resistant strains were those that showed resistance to at least 3 classes of antibiotics.

The dose of colistin was adjusted according to the creatinine clearance, calculated according to the Cockcroft-Gault equation [3].

Antibiotic therapy was carried out according to the local hospital protocol (which includes as well the list of reserve antibiotics), the antibiogram results and the patient profile.

The statistical analysis used Epilnfo programme, the $p$ threshold being considered statistically significant at a value of $<0.05$.

Results and discussions
During the study, there were $6135 \mathrm{Px}$ admitted, of whom $872(14.21 \%)$ presented urinary tract infections, with a proven bacterial etiology in 334 cases (38.31\%) (fig. 1).

The etiology of urinary tract infections was mainly

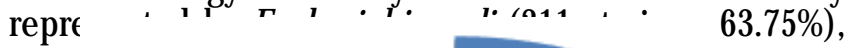

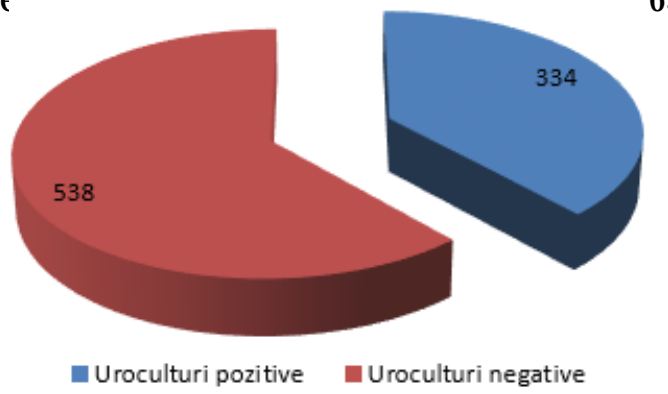

Fig. 1. Urinary tract infections with proven etiology

followed, at a distance, by Klebsiella pneumoniae (48 strains - 14.51\%) (fig. 2).

Multidrug resistant strains were highlighted in 22 cases (6.59\%), as follows: 3 strains of E. coli, 8strains of Klebsiella pn, 3 strains of Enterobacter spp., 2 strains of Proteus mirabilis, 6 strains of Pseudomonas aeruginosa.

For multidrug-resistant bacteria, antibiograms have shown a sensitivity to colistin of $68.19 \%$ ( 15 strains), to meropenem of $54.55 \%$ ( 12 strains), to amikacin of $27.27 \%$ (6strains) to fosfomycin of $18.18 \%$ (4 strains), to aztreonam of $13.64 \%$ ( 3 strains), to levofloxacin of $13,64 \%$ ( 3 strains), to cephalosporin: cefazolin $4.54 \%$ ( 1 strain), cefepime 4.54 $\%$ (1 strain), to amoxicillin-clavulanate of $4.54 \%$ ( 1 strain), to ampicillin, amoxicillin and co-trimoxazole of $0 \%$; a number of 6 strains $(27.27 \%$ ) were sensitive only to colistin. 


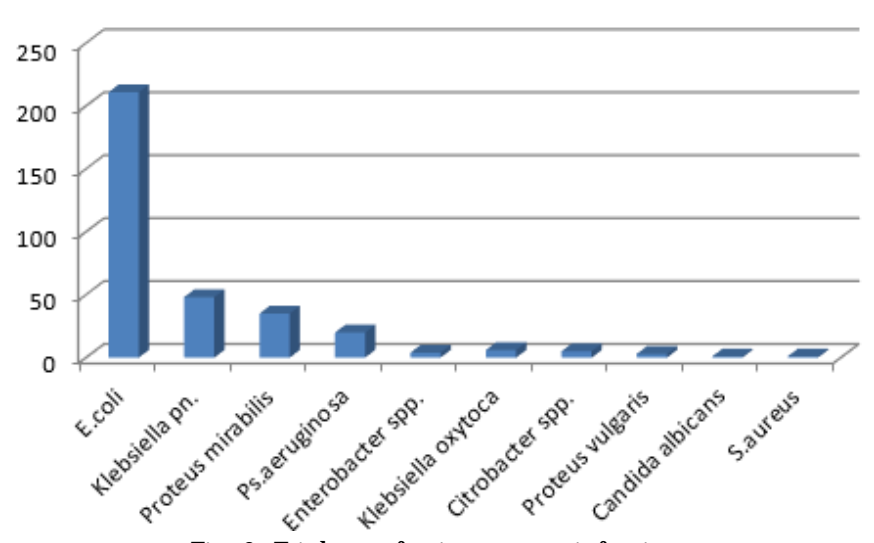

Fig. 2. Etiology of urinary tract infections

By analyzing the sensitivity phenotype of multidrugresistant bacteria to Colistin, the following data were obtained: all 3 strains of $E$. coli were sensitive, in the case of Enterobacter spp, 2 strains were sensitive, 1 strain sensitive to Proteus mirabilis, of 6 strains of $P$ s. aeruginosa 4 were sensitive and for Klebsiella pn., we registered 5 sensitive strains (fig.3).

Strains resistant to all classes of tested antibiotics were as follows: 1 case of Ps aeruqinosa and 1 case of Proteus

\section{Chart Title}

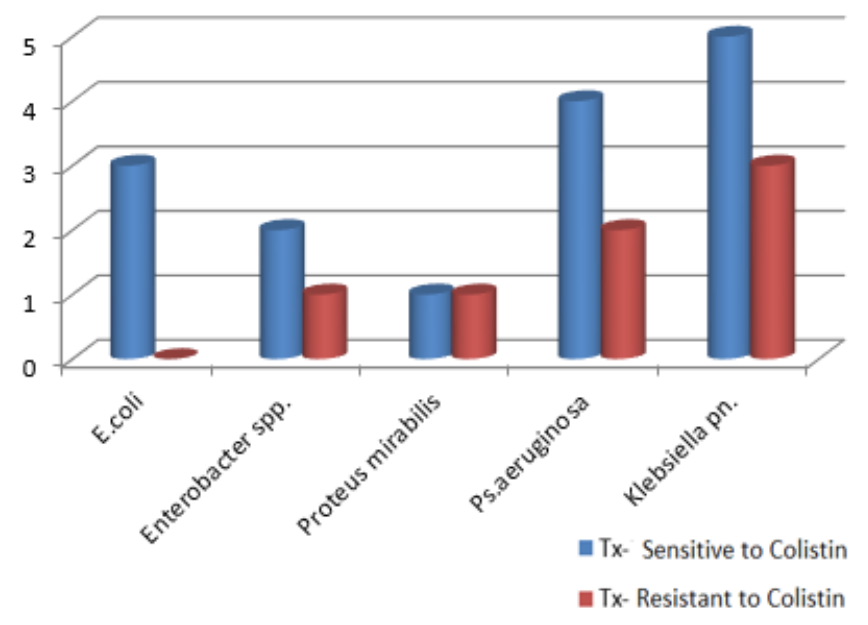

Fig. 3. Colistin sensitivity of multidrug resistant strains

mirabilis, both situations being noted in patients with longterm urinary catheter.

We performed a comparative analysis of colistin sensitivity and meropenem sensitivity of multidrug-resistant uropathogens and there was not obtained any statistically significant difference $(p=1,000)$ (table 1 ).

of $16 \mathrm{Px}$ with multidrug-resistant uropathogens to colistin, the treatment with colistin was indicated only for $12 \mathrm{Px}(75 \%)$, in all cases it was established depending on the antibiotic results ( 6 strains were sensitive to colistin

Table 1

COLISTIN SENSITIVITY VERSUS MEROPENEM SENSITIVITY IN CASE OF MULTIDRUG-RESISTANT STRAINS

\begin{tabular}{|c|c|c|}
\hline & $\begin{array}{c}\text { Tx sensitive to } \\
\text { Meropenem-no. } \\
(\%)\end{array}$ & $\begin{array}{c}\text { Tx resistant to } \\
\text { Meropenem-no. } \\
(\%)\end{array}$ \\
\hline $\begin{array}{c}\text { Tx sensitive to } \\
\text { Colistin-no. }(\%)\end{array}$ & $8(36.37 \%)$ & $7(31.81 \%)$ \\
\hline Tx resistant to & $4(18.19 \%)$ & $3(13.63 \%)$ \\
Colistin-no. $(\%)$ & & \\
\hline
\end{tabular}

alone, 1 strain to colistin and cefepime, 2 strains to aztreonam, amikacin and colistin, 3 strains were sensitive only to amikacin and colistin).

The characteristics of Px treated with colistin were as follows: the average age of Px was 68.12 years, the gender distribution was in favour of the male gender ( 9 Px-75\%), and the residence environment showed the presence of 7 Px (58.33\%) in rural areas. They presented the following comorbidities: $9 \mathrm{Px}$ with ischemic stroke, $3 \mathrm{Px}$ with stroke, $11 \mathrm{Px}$ with diabetes, $9 \mathrm{Px}$ with ischemic cardiomyopathy, $8 \mathrm{Px}$ with acute pneumonia, $7 \mathrm{Px}$ with chronic obstructive bronchopneumonia, $4 \mathrm{Px}$ with neoplasia, $3 \mathrm{Px}$ with chronic liver disease.

Colistin was intravenously administered as follows: the loading dose of 9 million IU ( 3 million IU every 8 hours) on the first day, afterwards 3-6 million IU / day, with a total duration of 10-14 days. In these Px, Colistin was not used in combination with other antibiotics.

Patients suffering of mild, functional kidney failure ( 3 cases) were given the dose of colistin, depending on the results of creatinine clearance, with creatinine monitoring at2-3 days and appropriate hydration, as well as nephrology examinations, without registering the worsening of renal function.

No adverse reactions were reported in any of the cases of colistin administration, Px being strictly monitored for: nephrotoxicity, neurotoxicity and hypersensitivity reactions.

Px evolution was favourable, with clinical healing (the disappearance of signs and symptoms of urinary tract infection), biological healing (normalization of white blood cell counts and inflammatory markers) and proven bacteriological healing (negative urocultures $72 \mathrm{~h}$ after treatment interruption) without registering any recurrence in the next 30 days; there were no deaths registered.

Urinary tract infections are a frequent pathology in neurologic $\mathrm{Px}$, the choice of antibiotic therapy representing a serious test for the clinician, due to the increasing antibiotic resistance, drug interactions, adverse reactions, as well as the Px profile with multiple comorbidities. Colistin is an etiological topical therapy, practically a re-emergence of antibiotic therapy, due to the change in the sensitivity phenotype, after a period in which it had almost been discontinued.

In our study, the sensitivity of multidrug-resistant microbes to colistin was average (68.19\%), but higher compared to the sensitivity to meropenem $(54.55 \%)$, without though a correlation between these antibiotics; the appearance is differentfrom the results of another study in which the risk of colistin resistance is increased in meropenem-resistant strains [5].

The most frequent multidrug-resistant uropathogen in this study was Klebsiella pn. The increase of Klebsiella pn resistance. to carbapenems has been reported in the last years, particularly in Europe, Romania being on the list of these countries, as of 2013 [4]. The acquired colistinresistance of Klebsiella pn. is rare, but it begins to become frequent in Italy [4].

The most frequently encountered adverse reactions to colistin are: nephrotoxicity and hypersensitivity reactions [6]. In our study, there was no registering of adverse event, unlike other studies [7;8], in which the only adverse reaction noted was nephrotoxicity in $25 \%-36.3 \%$ of $\mathrm{Px}$, or even higher of $53.5 \%$ [9], but the reaction was reversible after the treatment interruption. This difference can also be explained by the small number of Px in our group receiving colistin as their treatment.

The effectiveness of colistin in the treatment of urinary tract infections caused by multidrug-resistant bacteria proved to be excellent, in this study, clinical and 
bacteriological healing was proven in all cases treated with colistin, a similar aspect to other studies [7, 10-28].

Colistin resistance of multidrug-resistant bacteria is associated with the increase of mortality [4]; in the paper presented, Px evolution was favourable, which was possibly due to the preserved colistin sensitivity of uropathogens.

Our study is limited by: the discontinuities in antibiotic testing, reduced number of multi-drug resistant strains included, the short period of analysis and the reduced number of Px who received Colistin.

\section{Conclusions}

Urinary tract infections are frequently encountered in the neurologic patient, the major etiology being represented by $E$. coli; the risk of multidrug-resistance is not to be neglected, Klebsiella pn being the mostcommon in such a situation.

Colistin was the rescue therapy, with the best sensitivity in case of multidrug-resistant strains, a fact that recommends it in the future, as a backup antibiotic, but with strict monitoring of adverse reactions.

\section{References}

1. PAUL, V.M., BISHARA, J., LEVCOVICH, A., et al- Effectiveness and safety of colistin: prospective comparative cohort study in J Antimicrob Chemother, 2010; 65: 1019- p.27.

2. ETROSILLO, N., IOANNIDOU, E., FALAGAS, M.E.- Colistin monotherapy vs. combination therapy: evidence from microbiological, animal and clinical studies in Clin. Microbiol. Infect, 2008; 14, p. 816827.

3.COCKCROFT, D. W. and GAULT, M. H. - Prediction of creatinine clearance from serum creatinine. Nephron, 1976;16: p.31-41.

4. HAWKEY, P.M., WARREN, R.E., LIVERMORE, D.M., et al- Treatment of infections caused by multidrug-resistant Gram-negative bacteria: report of the British Society for Antimicrobial Chemotherapy/ Healthcare Infection Society/British Infection Association J oint Working Party in J ournal of Antimicrobial Chemotherapy, 2018; 73 (3)

5. STOIAN, A.C., CUPSA, A., DUMITRESCU, F. et al- Considerations about susceptibillity to antibiotics of uropathogenics Klebsiella pneumoniae strains in Therapeutics, pharmacology and clinical Toxicology, XIV ( 1), 2010, p.41-44.

6. POGUE, M.J., LEE, J., MARCHIAM, D., et al - Incidence of and risk factors for colistin- associated nephrotoxicity in a large academic health system in Clinical Infectious Diseases 2011; 53:879- p.84.

7. KARAKKATTU, J., MOHAN, A., J AMES, E., KUMAR, A.- Effectiveness and Safety of Colistin in Multi Drug Resistant Urinary Tract Infections in J ournal of Applied Pharmaceutical, 7 (09), 2017; p.148-152.

8. LUQUE, S., ESCANO, C., SORLI, L., et al- Urinary Concentrations of Colistimethate and Formed Colistin after Intravenous Administration in Patients with Multidrug-Resistant Gram-Negative Bacterial Infections in Antimicrob Agents Chemother, 61 (8), 2017.

9. SPAPEN, H., JACOBS, R., VAN GOUP, V., TROUBLEYN, J., HONORE. $P M$. Renal and neurological side effects of colistin in critically ill patients in Ann Intensive Care, 2011; 1, p.1-7.

10. PUIU, I., ALBU, C.V., TARTEA, E.A., CALBOREAN, V., GHEORMAN, V., DINESCU, S.N., VASILE, R.C., DINESCU, V.C., BICA, E.C., ROMANESCU, F.M., TUDORASCU, D.R. Relationships Between Glial Enteric Cells, Beta-cell Signaling and Tumor Proliferative Activity in Patients with Colorectal Neoplasia, Rev Chim (Bucharest), 69, no 10, 2018, p. 2744-2748.

11. TRASCA, S.P., FLORESCU, C., DINESCU, V.C., PUIU, I., DINESCU, S.N., TUDORASCU, D.R., BICA, C., VASILE, R.C., ROMANESCU, F.M., BUNESCU, M.G., CIOATERA, N., GOANTA, E.V. The Assessment of Percutaneous Coronary Angioplasty versus Coronary Artery Bypass Grafting in Treatment of Left Main Coronary Artery Disease. Rev Chim (Bucharest), 69, no.12, 2018, p.3600-3604.
12. BARBULESCU, A.L., CIUREA, P.L., MITRAN, C., CHISALAU, B.A., PARVANESCU, C.D., FIRULESCU, S.C., BALASOIU, M., BOLDEANU, M.V., POPOVICIU, H., VREJU, F.A., High frequency ultrasonography of the hand versus anti-RA33 evaluation in early rheumatoid arthritis - a pilot study, Med Ultrason, 19, no. 2, 2017, p. 166-171.

13. VREJU, F.A., CIUREA, M.E., POPA, D., POPA, F., PARVANESCU, C.D., CHISALAU, B.A., BARBULESCU, A.L., PARVANESCU, V., ROSU, A., CIUREA, P.L., Ultrasonography in the diagnosis and management of noninflammatory conditions of the hand and wrist, Med Ultrason, 18, no.1, 2016, p. 90-95.

14. BARBULESCU, A.L., VREJU, A.F., BUGA, A.M., SANDU, R.E., CRIVEANU, C., TUDORASCU, D.R., GHEONEA, I.A., CIUREA, P.L., Vascular endothelial growth factor in systemic lupus erythematosus - correlations with disease activity and nailfold capillaroscopy changes, Rom J Morphol Embryol., 56, no.3, 2015, p.1011-1016.

15.FIRULESCU, S.C., TUDORAa CU, D.R., PARVANESCU, C.D., CHISALAU, A.B., BASTIAN, A.E., EFREM, I.C., BARBULESCU, A.L., FORTOFOIU, M.C., CRIVEANU, C., IONESCU, P., DINESCU, S.C., TUDORANCEA, A.D., CIUREA, P.L., VREJU, A.F., The role of skin and muscle biopsy in the diagnosis of main connective tissue diseases, Rom J Morphol Embryol., 59, nr.1, 2018, p.55-64.

16. CIUREA, M.E., CIUREA, R.N., BÃRBULESCU, A.L., CHISALAU A.B., PARVANESCU, C.D., FIRULESCU, S.C., COVEI BÃNICIOIU, S., CIUREA, P.L., VREJU, A.F. Intramuscular hemangioma of the arm: ultrasonography and pathology features, Rom J Morph Embryol, 57, nr.2, 2016, p. 521-524.

17. TAISESCU, C.I., BICIUSCA, V., SAS, L., CAMEN, G., SAS, T., ALBU, C., TAISESCU, O. Changes of Visual Evoked Potentials in Patients with Thyroid Dysfunction,Rev. Chim. (Bucharest), 10, no.3, 2019, p. 961968.

18. TOADER, L.E., ROSU, G.C., CATALIN, B., PIRICI, I., GILCEAVA, I.C., ALBU, V.C., ISTRATE-OFITERU, A.M., MURESANU, D.F., PIRICI, D. Cerebrolysin increases motor recovery and decreases inflammation in a mouse model of autoimmune encephalitis. Romanian journal of morphology and embryology, 59, nr.3, 2018, p.755-762.

19. CODRINA, A., POMIRLEANU, C., IORDACHE, C., FATU, A.M., POPESCU, E., ANCUTA, E., MIHAILOV, C. Periodontal Disease and Lipid Profile in Systemic Sclerosis: an EUSTAR Cohort Experience. Rev. Chim. (Bucharest), 68, no. 4, 2017, p. 890-893.

20. SAVA, I. SAVA, A. SAPTE, E., MIHAILOV, C., DUMITRESCU, G., POEATÃ, I., SAVA, F., HABA, D. Intraventricular metastatic clear cell renal carcinoma. Rom J Morphol Embryol., 54, nr.2, 2013, p. 44750.

21. SANDU, R.E., UZONI, A., COMAN, C., POPA-WAGNER, A., Cerebral ischemia in the aged. Limited anti-inflammatory efficacy of the indomethacin treatment. Rom J Morphol Embryol., 56, nr.3, 2015, p. 1111-1117.

22. SANDU, R.E., DUMBRAVA, D., SURUGIU, R., GLAVAN D.G., GRESITA A, PETCU EB., Cellular and Molecular Mechanisms Underlying NonPharmaceutical Ischemic Stroke Therapy in Aged Subjects, Int J Mol Sci., 19, nr.1, 2017, pii: E99. doi: 10.3390/ijms19010099.

23. SANDU, R.E., BUGA, A.M., UZONI, A., PETCU, E.B., POPA-WAGNER, A., Neuroinflammation and comorbidities are frequently ignored factors in CNS pathology, Neural Regen Res., 10, nr.9, 2015, p. 13491355.

24. MUSTAFA, E.R., FIRULESCU, S.C., PARVANESCU, C.D., CHISALAU, B.A., TARTEA, G.C., EFREM, I.C., BARBULESCU, A.L., DINESCU, S.C., CIUREA, P.L., RADU, L, Triple valve endocarditis-a late diagnosis, J ournal of Mind and Medical Sciences, 5, nr.1, 2018, p.141-144.

25. FILIPPOU, G., SCIRE, C.A., ADINOLFI, A., DAMJANOV, N.S., CARRARA, G., BRUYN, G.A.W., CAZENAVE, T., D'AGOSTINO, M.A., DELLE SEDIE, A., DI SABATINO, V., DIAZ CORTES, M.E., FILIPPUCCI. E., GANDJBAKHCH, F., GUTIERREZ, M., MACCARTER, D.K., MICU, M., MOLLER PARERA, I., MOUTERDE, G., MORTADA, M.A., NAREDO, E., PINEDA, C., PORTA, F., REGINATO, A.M., SATULU, I., SCHMIDT, W.A., SERBAN, T., TERSLEV, L., VLAD, V., VREJU, F.A., ZUFFEREY, P., BOZIOS, P., TOSCANO, C., PICERNO, V., IAGNOCCO, A., Identification of 
calcium pyrophosphate deposition disease (CPPD) by ultrasound: reliability of the OMERACT definitions in an extended set of joints-an international multiobserver study by the OMERACT Calcium Pyrophosphate Deposition Disease Ultrasound Subtask Force, Ann Rheum Dis, 77, nr.8, 2018, p. 1195-1200.
26. POPA-WAGNER, A., BUGA, A.M., TICA, A.A., ALBU, C.V., Perfusion deficits, inflammation and aging precipitate depressive behavior, Biogerontology., 15, nr. 5, 2014, p. 439-448.

27. CATALIN, B., CUPIDO, A., IANCAU, M., ALBU, C.V., KIRCHHOFF, F., Microglia: first responders in the central nervous system, Rom J Morphol Embryol., 54, nr.3, 2013, p. 467-472.

28. ALBU, C.V., PADUREANU, V., BOLDEANU, M.V., BUMBEA, A.M., ENESCU, A.S., ALBULESCU, D.M., SILOSI, C.A., ENESCU, A., Vascular neurocognitive disorders and the vascular risk factors, Journal of mind and medical sciences, 5, nr.1, 2018, p. 7-15.

Manuscript received: 14.05 .2018 